\title{
Scholarship and the Academic Librarian
}

\section{William K. Black and Joan M. Leysen}

\begin{abstract}
In order for librarians to succeed within the academic model, an environment must be established that recognizes the interplay of activities in the three areas of performance (teaching, research, and service). This environment requires clear criteria for performance, opportunities for and assistance with scholarly activities, a schedule that is conducive to the academic model, clear delineation of faculty and support staff responsibilities, adequate training, and broad criteria for assessing contributions. This article addresses the importance of $a$ holistic view to the academic model of librarianship and suggests a system for providing support and judging performance.
\end{abstract}

\section{THE CONDUCIVE ENVIRONMENT}

\section{The Academic Model}

The unique role of librarians in the educational process is often recognized through a special academic or faculty status that promotes the concept that librarians, like their counterparts in the teaching faculty, are significant contributors to the academic enterprise. Frequently this is recognized by a three-tiered structure requiring performance in teaching (professional practice), scholarship, and service. ${ }^{1}$

The philosophy surrounding this model promotes the concept of librarians as academicians by recognizing that they participate in the educational mission of the institution by providing information and services which enhance the advancement of learning and research. They do this through direct work with users or indirectly through acquiring, organizing, interpreting, and/or administering library resources or programs. In this manner they fulfill a unique teach- ing function by bringing the quest for knowledge together with available information resources. They are also active in collegiate citizenship; namely, they are involved in library and university governance structures through committee service as well as community outreach.

Further, librarians disseminate the results of their work through publications, lectures, exhibits, and participation in appropriate technical, professional, and scholarly societies reflecting their research reputations. Contributions to the practice of librarianship, scholarly work, and institutional and professional service each form a vital and dynamic part of the composite picture of the librarian within the academic context. This holistic view is particularly important in recognizing the contribution that librarians make to the educational process. It has been difficult for many academic libraries to provide the environment necessary to foster, assess, and promote this view, particularly with regard to scholarly contributions.

William K. Black is Associate Professor, Library Development and Project Management; Joan M. Leysen is Assistant Professor, Monographs Copy Cataloging, Iowa State University, Ames, Iowa 50011. Both authors serve on the library's Promotion and Tenure Review Committee. 


\section{The Scholarship Component}

Benefits. The academic model for librarians assumes that scholarly activity is beneficial to the practice of librarianship. The research component can strengthen reference, cataloging, and collections activities. It often sharpens skills and broadens perspectives for the daily services provided and produces a beneficial effect on other aspects of the job assignment. Dwight F. Burlingame and Joan Repp's survey of librarians revealed that 44.2 percent of those who published thought publication was a positive aspect of library service. ${ }^{2} \mathrm{Re}-$ search can provide a sense of self-satisfaction that comes from communicating one's ideas to a broader audience, building an area of expertise, and receiving recognition within and outside promotion, tenure, or salary allocation. ${ }^{3}$ It can promote strong relationships with teaching faculty, enhance beneficial comprehension of the research process, and facilitate concrete understanding of the access and service needs of the library clientele. Research fosters a broad perspective of the field, strengthens librarians' knowledge of current issues, shapes the dialogue surrounding those issues, and leads to innovative approaches and a responsiveness to change. ${ }^{4}$

Obstacles. The particular designation of faculty status for librarians has engendered debate over the years as to its appropriateness and achievability. Much of the debate has centered on the scholarly component of this faculty model which often encourages or requires publication. Librarians often have difficulty meeting scholarship expectations because of the structure of their work environment and the way in which the institution and librarians themselves perceive scholarship. W. Bede Mitchell and L. Stanislava Swieszkowski's survey of member institutions of the Center for Research Libraries found that in libraries where publication is required for tenure, failure to perform and disseminate research was the most frequent reason for being denied tenure. ${ }^{5}$ The scholarship component may be viewed as an additional burden to the job expectations rather than as an integral component of a total picture. This view of librarianship, the atomistic view, separates professional practice from scholarship and service, and splinters what is designed to be a cohesive and complementary process.

Others see a conflict between service to users and research expectations. If librarians are required to perform research, the quality of library service could diminish. ${ }^{6}$ Still others are uncertain as to the criteria for performance and promotion/tenure review. Often librarians are overwhelmed by the process. Guidelines seem complex and confusing, or they may not be easily accessible. Some resources for funding or other support may be oral traditions that are not broadly known. At times, individual faculty may not utilize adequate initiative to discover available support systems.

\section{Librarians often have difficulty meeting scholarship expectations because of the structure of their work environment and the way in which the institution and librarians themselves perceive scholarship.}

The work schedule is often cited as a primary hinderance to the production of quality scholarship. Parallels are frequently drawn with teaching faculty who experience a schedule that is often seen as more conducive to participation in the three-tiered faculty structure. "Most academic librarians work under twelve-month contracts, do not receive salaries equal to those of teaching faculty with the same rank, do not enjoy a flexible work day and week, and are not provided with the compensatory release time necessary for them to contribute in a scholarly manner to their field."

\section{Creating A Supportive Structure}

If we are to expect librarians to contribute within the faculty structure in the areas of professional practice, scholarship, and service, then we must be prepared to provide the structure necessary 
for success. This should include ensuring clear, consistent, and well communicated criteria for performance, providing a system of regular performance review, building in a supporting structure and mentoring system to aid librarians in meeting established criteria, and creating an environment in which librarians see their role as holistic (and, in fact, synergistic) rather than composed of individual and separate parts.

Criteria. National standards developed by ACRL provide a framework for development of institutional performance expectations. ${ }^{8}$ Criteria for promotion and tenure will vary from one institution to another depending upon individual type and mission, and the particular status accorded librarians.' Such criteria generally outline expectations and a review process for performance. Often, however, these expectations, particularly in regard to research and publication, may not be explicitly defined. ${ }^{10} \mathrm{As}$ Janet Krompart and Clara DiFelice report, "both librarians and directors are often uncertain about librarian scholarship responsibilities and benefits at their institutions. Confusion among librarians about the achievements necessary for favorable personnel reviews and/or promotion appeared persistently in early and late survey findings." 11

It is incumbent upon us to ensure that performance criteria are consistent, current, and broadly disseminated. All librarians must understand what is required. Clear job expectations should be agreed to each year as part of an annual work plan. Such a plan should be part of the performance appraisal process and needs to recognize the requirement of the faculty to contribute successfully in each area of their job assignment (professional practice, scholarship, and service). The work plan, the promotion and tenure criteria, and the annual performance evaluation instrument must be consistent in the factors measured and in the way they are assessed. Sessions should be scheduled both within the context of the annual performance discussion and during the promotion and tenure process to pro- vide a dependable mechanism for regular feedback. Consistency between the annual review and the promotion and tenure review processes will result in unified expectations.

\section{Since scholarship is an integral part of the faculty responsibility, the schedule of assignments must include an opportunity to perform scholarly work.}

Making Scholarship Meaningful. In order to be successful in promoting scholarship in the assignment and assessment of job responsibilities for librarians, scholarship should be meaningful and relevant to the individual position assignment. Since scholarship is an integral part of the faculty responsibility, the schedule of assignments must include an opportunity to perform scholarly work. Ideas for scholarly projects should come, at least to some extent, from the daily work of the librarian who is involved in planning and developing services and programs and in making decisions related to them. This will promote easier identification of topics and relevance to the work situation. Identifying and creating new reference resources, developing a better interface for accessing a database, and preparing an index to a volume or collection, are all examples of scholarly activities that could be initiated by a question at the reference desk. While cataloging a large volume of materials in one subject area, the cataloger might discover a gap in an area of the classification schedules and propose a new scheme or modification to the schedule. Publication of this proposal would assist other libraries in cataloging similar collections. Work with new technology, such as text digitization in interlibrary loan or artificial intelligence in acquisitions, can be applied to routine tasks to measure their impact on patterns of information requests. Work in the area of collection development, policy setting, and human and programmatic resource management can lend it- 
self to the investigation and production of scholarly works. With increasing responsibility for divergent aspects of library service on the part of many librarians, links between multiple facets of job responsibilities should be provided.

Library faculty may write instructions, procedures, and evaluations as part of their daily responsibilities. Others may have opportunities to participate in preparing written in-house reports that include analysis and interpretation of user services or that study the impact of a new technology or enhancement to current workflow. Betsy Baker suggests librarians conduct "action research" which utilizes observation and conversation to study existing conditions (such as library services) and make recommendations to improve or resolve those conditions. This research is "conceived and carried out in practiceby practitioners."12

It is easy to view the cataloging or reference work that librarians do as the primary job to the exclusion of the other facets of their responsibilities. In the academic model, this is shortchanging all components. There should be a real continuity between professional practice, research, and service, and we need to appreciate the benefits inherent in this relationship.

Mentoring. Some librarians do not have the requisite skills to conduct library research. Others may be uncertain about the publishing process and where to look for appropriate publishing outlets. Still others need help in focusing ideas into significant works. Certain librarians may have good composition skills yet may lack knowledge of research methodology and statistical analysis. While some library schools provide instruction in research skills in order to enhance this capability, the socialization of librarians to the academic model lacks the full mentoring structure evident in the graduate programs of many other disciplines. The educational preparation of academic librarians could include a better acculturation to the academic model and its expectations for research. ${ }^{13}$ Skills development and opportunities for mentoring and collaboration should be made available to librarians once they are hired. The American Library Association has recognized the need for research skills among librarians and has devoted preconferences to training and development in this area. Some libraries have small-group meetings where research ideas are contributed and discussed. Many librarians can take advantage of advice and counsel from colleagues who are prolific authors or who serve on editorial boards. These individuals should be acknowledged for serving as mentors in the organization.

Other institutions have established resource centers consisting of manuscript guidelines for a number of journals, time-lines and instructions for grant applications, and copies of published articles by the faculty. The Auraria Library created a Research Center in 1987 to collect information supportive of the research process, addressing such matters as manuscript preparation, publication guidelines, and examples of topics and methodologies. ${ }^{14}$ Presentations at library meetings about the promotion and tenure criteria as well as discussion of current research projects will boost morale, produce incentive, and provide ideas. An internal committee might help match research opportunities in a specific area with individuals whose interest or experience is in the same area. Opportunities abound for cooperative research projects that are particularly useful when additional expertise or support is needed.

Schedule. Librarians often cite the schedule as a barrier to successful completion of expectations in the three-tiered faculty structure. Librarians working within the academic model will often ask, "How am I going to accomplish all of my reference work, carry out my committee assignments as expected, participate in the profession, and perform research when I'm required to work every day, twelve months a year?" While it is not the schedule alone that causes difficulty in meeting expectations, it is certainly a primary area of concern. 
Time for performing research and service should be structured into the work day just as time for cataloging and service to the institution and the profession is provided. Otherwise, participating in the scholarly process has too many starts and stops, producing a lack of momentum resulting in an obstacle to constructive research. ${ }^{15}$ A number of programs are in place at different institutions to provide librarians with opportunities for performing in all areas of their assignment. These have included the designation of assigned and unassigned time, setting aside a specific amount of time for research or consulting, offering leaves of up to two weeks for work on special projects away from the press of daily responsibilities, longterm leaves such as sabbaticals, and occasionally nine-month contracts that parallel those of the teaching faculty. Frank and Allie Goudy report on a schedule at Western Illinois University based on CUEs (credit unit equivalencies). "Scheduled CUEs mandate that a person be specifically accountable for their presence, while unscheduled CUEs allow library faculty members to conduct their activities at their own discretion, like teaching faculty .... without being required to report their location to their department chairs. In no case would a library faculty member be scheduled less than eighteen hours nor more than twentyfour hours per week."16 In this organization, all research-related activities including attendance at professional meetings are performed during unscheduled CUE time.

Release time is frequently cited as a solution to complaints of lack of time for research activities. Responses from sixty-eight ARL directors reported that thirty-five libraries had some form of release time. ${ }^{17}$ Shelley Arlen and Nedria Santizo reported a similar finding. "Few of those librarians required to publish report allocation of a specific amount of release time during the work week $(7 \%)$, but almost one-third answered that limited release time (two to eight hours per week) is available upon request." 18 The same study also revealed that where li- brarians had the autonomy to schedule their work time, they also were more likely to have written release time policies. A written policy on release time provides the assurance by administration "that research is a valued and significant part of a faculty member's professional life.... A written policy also informs support staff of the importance of research activities." 19

\section{Viewing librarianship as an eight-to-five job that requires constant job presence severely limits the librarian's ability to meet promotion and tenure expectations.}

While release time does allow librarians to perform scholarly activities without interruption of the daily duties, some may be reluctant to take (or support) such leave if it means a reduction in the level of service to library users, an increase in the backlog of day-to-day activities, additional burden for colleagues, or if it is tied to a specific publishing expectation within an unachievable time frame.

Even the term release time may not be the best. How can you be released from something that is integral to your assignment? Just as in the teaching faculty model, research must be seen as a part of what library faculty do. "Since research, along with other professional activities, is considered part of the job, one does not need to be released from one's duties to pursue research. ${ }^{20}$ In the academic model, research must blend into a cohesive whole with each of the parts providing important benefits for the others. We do not perform reference work, serve on library committees, participate in ALA groups, and conduct research and writing, separately. Each activity reflects upon and benefits the others, and the schedule should recognize that fact.

If we look at the librarian's job within the academic model, it should not be based upon time or job presence but rather on what core responsibilities are 
expected in the areas of professional practice, scholarship, and service. The schedule should recognize the importance of, and allow for contributions in, all areas of the assignment. How can we expect librarians to contribute fully if we mandate a schedule that impairs their ability to succeed? Viewing librarianship as an eight-to-five job that requires constant job presence severely limits the librarian's ability to meet promotion and tenure expectations. Recent dialogue on electronic listservs, as well as discussion in ALA meetings, has frequently been devoted to such topics as release time, telecommuting, and other alternatives to the standard work schedule. We need to take a much broader view, constructing expectations and time commitments based upon professional practice and scholarship and service.

Distinguishing Faculty Responsibilities. In order to provide an environment that promotes successful performance, activities need to be defined appropriately as to whether they are most effectively carried out by librarians or by other staff. Alan Veaner states that, "one key to the improvement of librarians' academic status may be further off-loading of their production work onto support staff. For librarians to reach genuine parity with faculty, it is necessary to get librarians completely out of the 'manufacturing' business." ${ }^{21}$ In a project at the University of Florida, catalogers worked as a team with paraprofessionals to prepare original cataloging records. Paraprofessionals performed descriptive cataloging and the professionals completed the classification and subject analysis. While the overall time to complete a record may not be improved, the time the professional cataloger has to spend on cataloging is utilized effectively. ${ }^{22}$ While librarians and support personnel both serve extremely valuable roles, those roles are different. Responsibilities should be clarified to determine what is appropriate at each level. This will help in allocating duties correctly at every level within the organization. By properly designating work routines and assignments, librarians will be able to establish the appropriate context for their work.

Training. Effective training programs for support personnel will ensure that properly designated work is effectively carried out. This will involve providing a clear explanation of the role of the librarian in the organization, and promoting understanding between different categories of employees regarding the important and unique roles carried out in the library by each group. The responsibilities of librarians within the academic model go beyond their desk work as reference librarians, catalogers, acquisitions staff, or bibliographers. This needs to be understood and supported within the library environment in order to maintain a cooperative and effective system.

Support. Adequate financial and service support is also necessary. Financial support is needed for literature searches, guidance in preparing grants, and funding to attend conferences where librarians can network with others to stimulate ideas for research. Support services and expertise at the institutional level also facilitate research activity. Librarians need to know where they can find clerical, computer, and statistical assistance. This need not take large amounts of money. Often it simply requires organization and communication.

Assistance and support should be clear, concise, and easy to obtain. The procedures for requesting help should be simple and straightforward, providing the highest benefit for the least investment of effort. Librarians involved in the scholarship process should spend their time performing research and writing, not trying to figure out the process. An effective support system for research and publication is essential to the scholarly success of the faculty.

\section{ASSESSING SCHOLARSHIP COMPETENCE \\ Evaluating Contributions}

Standards. Within the faculty environment, there will exist many forms of scholarship and a number of evaluative systems for assessing those contribu- 
tions. Each academic unit at the institution will produce different kinds of research that are weighed against unit-level criteria that account for particular differences in the discipline and yet still meet an overall qualitative standard for scholarship. While the contributions will vary in content and form and the assessment will take into account the unique nature of the individual discipline, works will all be of an overall quality, matching institutional minimum criteria and contributing to the body of scholarly knowledge in the particular field. The Association of College and Research Libraries' standards call for review procedures that conform to those utilized for other faculty at the same institution. ${ }^{23}$ Quantitative criteria are less persuasive than the quality of the works reviewed. Ronald Rayman and Frank Goudy's study found that of the ten libraries requiring publication, none had quantitative standards. ${ }^{24}$ Still, quantity is at least a factor in some promotion and tenure systems. An Association of Research Libraries study found that some libraries use general quantitative terms such as "at least two or three substantial articles," "one book," or "four reviews." 25

For librarianship, where individuals have additional advanced degrees in increasing numbers, it is appropriate to view the field in broad terms, recognizing the unique nature of the discipline as well as the particular backgrounds of the faculty. The system for assessing scholarship must allow for contributions that reflect this broad, interdisciplinary nature of librarianship. Standards, while being appropriate to the field, must meet the general criteria for quality that exist at the institutional level. This is feasible if clear criteria are written that reflect the unique character of the profession and measure scholarship with a system that reflects high standards for contributions to the field. Such a system must be comparable, not necessarily identical, to those of other campus units. ${ }^{26}$

Activities in the area of scholarship have proven difficult for academic library promotion and tenure review committees to assess. Review committees traditionally struggle with such questions as: What gets counted? How do published articles in journals compare with contributed papers, editorships, and poster sessions? How do we assess quality in the production of scholarship? What about the quality of the journal? How are contributions weighed? What about coauthored works? How much is enough?

Since the field of librarianship is a broadly interdisciplinary one, it is appropriate to consider a wide range of contributions relevant to the faculty member's appointment.

Categories of Research. Contributions to the field of scholarly knowledge may include the publication of research, creation of new works, presentation of knowledge in new forms, and/or innovative application of knowledge, processes, or methodology within the field. These may present themselves in various forms such as books, book chapters, journal articles, annotated bibliographies, translations, book reviews, literature guides, published papers, or presentations. Participation in the scholarly process can take the form of author, editor, presenter, or exhibitor. In addition, recognition of scholarly achievement in the form of appointments, invitations, or awards is pertinent to the candidate's scholarly reputation. Since the field of librarianship is a broadly interdisciplinary one, it is appropriate to consider a wide range of contributions relevant to the faculty member's appointment. This appointment will include all aspects of position expectations, not just the individual's responsibilities as reference librarian, cataloger, systems librarian, bibliographer, and so forth.

For the purposes of promotion and tenure review, scholarship performed by librarians can be divided into five general areas: original research, including books, chapters in books, articles in major journals, papers presented at 
conferences, and authorship of grants reflecting original research; secondary research, including authored works (as editor), annotated bibliographies, anthologies, collected works, and grants reflecting secondary research; work evaluating the scholarly contributions of others, including editorial board responsibilities, serial editorships, book reviews, and serving as a juror of creative works; creative activities, including exhibits, software development, and instructional design; and complementary research, including presentations, exhibits, position papers, poster sessions, in-house reports, and newsletter columns. This is not an exhaustive list, since there are certainly other means of contributing in scholarship, but it will serve to indicate the types of activities that are generally undertaken. As technology continues to impact the way librarians work, new opportunities will develop that offer additional avenues for contributing to the body of scholarly knowledge.

Again, opportunities for contributing scholarship should extend beyond the faculty member's particular position to the broader arena of the faculty assignment. Work in the area of scholarship should be a reflection of the individual's experience, education, and/or professional expertise that is relevant to the faculty assignment. While colleagues in the rest of the faculty work in areas that are, for the most part, more narrow, the field of librarianship provides a broad arena in which to operate, including a variety of formats encompassing many disciplines. The point here is to provide a broad spectrum of possibilities for contribution and dissemination while at the same time expecting relevance to the field in which the faculty member works.

Evaluative Factors. While defining the opportunities broadly, we must, at the same time, have appropriate standards for such work. In assessing scholarly contributions, review bodies will want to consider such factors as the reputation of the journal in which the work appears, the importance/relevance of the topic to the profession, the extent of originality/creativity in the writing and re- searching of the work, the degree to which the piece breaks new ground, and whether or not the work adds to the body of scholarly knowledge. The review process, then, is a critical one which must have clear and well-disseminated criteria. The successful review system involves an evaluation of all pertinent documentation in accordance with the written criteria for promotion and tenure, including material provided by the candidate, the letters of reference from evaluators, and a comparative review of the individual's scholarly work with appropriate benchmarks in the field. Extramural review by individuals qualified to comment upon the candidate's accomplishments is often a part of this review process. The intent is to obtain the broadest possible assessment so that a thorough evaluation can take place. Model criteria are suggested in appendix A.

The Work. The full picture of the candidate's expertise in the area of scholarship should be drawn from the range of contributions presented. Each activity that reflects research has a place in the scholarship assessment. Activities should be judged individually on their own merits and then brought together to form a cohesive picture of the candidate's professional competence. This will involve a review of many different activities. While completed research and scholarship are normally accepted for publication in quality journals and judged on their ability to incorporate research, reflect a knowledge of the broader field, and contribute to the body of scholarly knowledge, other works will often be present and will need to be assessed.

The definition of significance for scholarly contributions varies at each institution and during different time periods. As Rodney Hersberger states, "In the earlier days of faculty status at many schools, the preparation of in-house bibliographies or internal reports was often considered a 'publishing' activity." ${ }^{27}$ Today, according to Betsy Park and Robert Riggs, in-house publications receive less acceptance. ${ }^{28}$ There is a common hierarchy among scholarly works that weighs 
books, chapters, or articles more highly than presented papers, articles with local focus, or in-house reports; articles in refereed publications usually carry more weight in promotion and tenure considerations than works in nonrefereed or in-house publications. ${ }^{29}$ The particular hierarchy accorded to works, the degree of research and scholarship inherent in them, the actual type of contribution (e.g., chapter, refereed article, conference paper), the scope required, and the centrality to the job assignment or the field itself will vary from one library to another depending upon the goals, environment, and mission of the institution. ${ }^{30}$

The Author. As the review takes place in the area of scholarship, it is appropriate to consider the qualifications of the candidate with regard to his or her scholarly contributions. This may include an assessment of the author's qualifications to speak to the issues, the expertise apparent in the work, how well the author displays a knowledge of the larger field, and the ability of the author to assess trends, provide a proper framework, and draw conclusions.

It is important also to consider the nature of individual involvement in coauthored works, the level of accomplishment on works in progress, effort reflecting scholarship and research that results in unpublished work such as major in-house reports, presentations, papers, and awards that recognize scholarship reputation. In the case of coauthored works, the candidate should describe the nature of his or her contribution. It is our feeling that although coauthored works are treated in varying ways at different institutions, they should be viewed in a similar manner as singleauthored works. We should promote and encourage collaboration between those colleagues who share complementary professional interests. As in the sciences, collegial support and formal and informal mechanisms for collaboration need to be developed and encouraged. ${ }^{31}$

Means of Dissemination. Scholarly works created by librarians can be disseminated through a variety of printed forms such as journals (refereed and nonrefereed), monographic publications, conference proceedings, and publications of library associations. In addition, opportunities now exist for publication in electronic formats. In the interdisciplinary field of librarianship, it is logical to define broadly the nature of scholarly contributions and their means of dissemination. Contributions will be judged in part on the quality of the forum in which they are disseminated.

An article may not always need to appear in the most prestigious journal but perhaps should be published where it will reach a more specifically defined or a wider audience.

The primary vehicle for distributing scholarly work remains the journal article. The journal provides "theopportunity for dissemination of a larger number and broader scope of issues and questions; intensive study of very specific questions or aspects of large problems; and the timely publication of intended communication (though this last item may be a disputed point on both sides of the editorial fence)." ${ }^{\prime 32}$ The journal article is also the forum most acceptable to libraries. Ninety-two (73.6 percent) of the faculty status institutions surveyed by Park and Riggs indicated publications in refereed journals were acceptable in their promotion and tenure process. ${ }^{33}$

Several core lists of journals have emerged from studies of the literature of librarianship. John M. Budd and Charles A. Seavey selected thirty-six journals which "are national in scope, contain some portion of their content that is judged relevant to the academic enterprise, and are likely to be looked upon favorably in promotion and tenure reviews." Many of the same journals have been named in other studies and by library educators and academic library directors as being significant in promotion and tenure decisions. ${ }^{35}$ "Whether these rankings reflect an actual hierarchy of journal importance or whether they merely group journals into clusters 
of high and low prestige, members of the academic community do use them to identify top library and information science (LIS) journals." ${ }^{36}$

While these journals provide standards for the profession and continue to be excellent sources for disseminating research, librarians should also consider institutional standards which may give greater weight to certain types of journals. Other publication opportunities that should be explored include newer journals (e.g., Journal of Interlibrary Loan \& Information Supply), sources appropriate to related fields, particularly with regard to collaborative efforts, and sources befitting cross-disciplinary work. The intended audience for one's ideas can influence the journal selected. An article may not always need to appear in the most prestigious journal but perhaps should be published where it will reach a more specifically defined or a wider audience. A new computerized approach to teaching bibliographic instruction may be more suitable in an instructional design or computer-related publication than in the traditional library journal. Beginning researchers may want to distribute their ideas to a smaller audience such as a state or regional publication that may be a nonrefereed journal. While the nature of the publication forum will be considered in a review of scholarly effort, the quality of the work itself is of greatest importance. Its dissemination should be appropriate to its nature, purpose, and audience.

\section{CONCLUSION}

While there are adjustments that are necessary in bridging librarians into the faculty model, the concept promotes a holistic view of librarians that is beneficial to their role as educators and information specialists. The model recognizes the primary role for librarians in learning and research, fosters responsibility for thinking about and contributing to the academic process, and offers an opportunity for career growth, relationships with the teaching faculty, and symbiosis among the teaching, research, and service functions of academic librarianship. It is incumbent upon us to provide an environment conducive to the successful implementation of this model-one that provides clear and appropriate criteria, an opportunity for active participation, a positive environment for success, and a fair system of review. If we expect competent performance of our librarians within the faculty model, then we must provide the knowledge, opportunities, and feedback that will foster that success.

\section{REFERENCES AND NOTES}

1. A recent study indicated that 67 percent of U.S. institutions of higher education have faculty status for their librarians. Charles B. Lowry, "The Status of Faculty Status for Academic Librarians: A Twenty-year Perspective," College \& Research Libraries 54 (Mar. 1993): 165. Numbers of institutions with faculty status for librarians vary depending on the classification of institutions included in the survey pool and the definition of faculty status. See, for example, Betsy Park and Robert Riggs, "Tenure and Promotion: A Study of Practices by Institutional Type," Journal of Academic Librarianship 19 (May 1993): 73; "Tenure and Retrenchment Practices in Higher Education: A Technical Report," Journal of the College and University Personnel Association 31 (Fall/Winter 1980): 26; Thomas G. English, "Librarian Status in Eighty-nine U.S. Academic Institutions of the Association of Research Libraries: 1982," College \& Research Libraries 44 (May 1983): 207; Ronald Rayman and Frank Wm. Goudy, "Research and Publication Requirements in University Libraries," College \& Research Libraries 41 (Jan. 1980): 44. Regardless of how it is defined, faculty status for librarians continues to be a prevalent method for bringing academic libraries into the educational enterprise. 
2. Dwight F. Burlingame and Joan Repp, "Factors Associated with Academic Librarians' Publishing in the 70s: Prologue for the 80s," in Options for the 80s: Proceedings of the Second National Conference of the Association of College and Research Libraries. Foundations in Library and Information Science, vol. 17, Pt.B., eds. Michael D. Kathman and Virgil F. Massman (Greenwich, Conn.: JAI, 1982), 400.

3. Dale S. Montanelli and Patricia F. Stenstrom, "The Benefits of Research for Academic Librarians and the Institutions They Serve," College \& Research Libraries 47 (Sept. 1986): 483.

4. JoAnne Hall, "The Relationship between Innovation or Change Agent Characteristics of Academic Librarians in the Southeastern United States" (Ph.D. diss., University of Michigan, 1984, cited in Montanelli and Stenstrom, "The Benefits of Research for Academic Librarians"), 484.

5. W. Bede Mitchell and L. Stanislava Swieszkowski, "Publication Requirements and Tenure Approval Rates: An Issue for Academic Librarians," College \& Research Libraries 46 (May 1985): 252.

6. Willis Bridegam, "A Research Requirement for Librarians?" Journal of Academic Librarianship 4 (July 1978): 135.

7. Emily Werrell and Laura Sullivan, "Faculty Status for Academic Librarians: A Review of the Literature," College \& Research Libraries 48 (Mar. 1987): 96.

8. Association of College and Research Libraries, Academic Status Committee, "Model Statement of Criteria and Procedures for Appointment, Promotion in Academic Rank, and Tenure for College and University Librarians, College \& Research Libraries News 48 (May 1987): 247-54; Association of College and Research Libraries, Academic Status Committee, "Standards for Faculty Status for College and University Librarians," College \& Research Libraries News 53 (May 1992): 317-18.

9. Park and Riggs, "Tenure and Promotion," 74-77.

10. Betsy Park and Robert Riggs, "Status of the Profession: A 1989 National Survey of Tenure and Promotion Policies for Academic Librarians," College \& Research Libraries 52 (May 1991): 282-83.

11. Janet Krompart and Clara DiFelice, "A Review of Faculty Status Surveys, 1971-1984," Journal of Academic Librarianship 13 (Mar. 1987): 16.

12. Betsy K. Baker, "Using the Results: Applying Research to Daily Operations" (Paper presented at "Investigating the Enterprise: The Brave New World of Library Research," Iowa Library Association/Association of College and Research Libraries Spring Conference, Ft. Dodge, Iowa, Apr. 30, 1993).

13. W. Bede Mitchell and Bruce Morton, "On Becoming Faculty Librarians: Acculturation Problems and Remedies," College \& Research Libraries 53 (Sept. 1992): 384-87.

14. Kathleen Kenny, Linda D. Tietjen, and Rutherford W. Witthus, "Increasing Scholarly Productivity among Library Faculty: Strategies for a Medium-Sized Library," Journal of Academic Librarianship 16 (Nov. 1990): 278.

15. Robert Boice and Ferdinand Jones, "Why Academicians Don't Write," Journal of Higher Education 55 (Sept./Oct. 1984): 568.

16. Frank William Goudy and Allie Wise Goudy, "The Dilemma of Library Faculty Workload: One Solution," Library Administration \& Management 2 (Jan. 1988): 37-38.

17. Rayman and Goudy, "Research and Publication Requirements in University Libraries," 45.

18. Shelley Arlen and Nedria Santizo, "Administrative Support for Research: A Survey of Library Faculty," Library Administration \& Management 4 (Fall 1990): 209.

19. Ibid., 211.

20. Robert G. Sewell, "Faculty Status and Librarians: The Rationale and the Case of Illinois," College \& Research Libraries 44 (May 1983): 219.

21. Allen B. Veaner, " 1985 to 1995 : The Next Decade in Academic Librarianship, Part I," College \& Research Libraries 46 (May 1985): 216-17.

22. Carol Walton and Cecilia Botero, "Offloading or Staff Development? Team Cataloging at the University of Florida," Cataloging \& Classification Quarterly 15 (1992): 62.

23. Association of College and Research Libraries, Academic Status Committee, "Standards for Faculty Status for College and University Librarians," 317-18.

24. Rayman and Goudy, "Research and Publication Requirements in University Libraries," 47. 
25. Jack Siggins, compiler, Academic Status for Librarians in ARL Libraries, SPEC (Systems and Procedures Exchange Center) Kit 182. (Association of Research Libraries, Office of Management Services, Mar. 1992).

26. A similar view is expressed by John M. Budd and Charles A. Seavey, "Characteristics of Journal Authorship by Academic Librarians," College \& Research Libraries 51 (Sept. 1990): 465; Werrell and Sullivan, "Faculty Status for Academic Librarians," 97.

27. Rodney M. Hersberger, "The Challenges of Leading and Managing Faculty Status Librarians," Journal of Academic Librarianship 14 (Jan. 1989): 362.

28. Park and Riggs, "Status of the Profession," 282.

29. John Cosgriff, Donald Kenney, and Gail McMillan, "Support for Publishing at Academic Libraries: How Much Exists?" Journal of Academic Librarianship 16 (May 1990): 96.

30. The acceptability and significance of publications outside the field of librarianship is frequently debated. Priscilla Geahigan, Harriet Nelson, Stewart Saunders, and Lawrence Woods, "Acceptability of Non-Library/ Information Science Publications in the Promotion and Tenure of Academic Librarians," College \& Research Libraries 42 (Nov. 1981): 571-75; Siggins, Academic Status for Librarians in ARL Libraries, SPEC Kit 182. Of the twenty-one promotion and tenure documents reviewed in the SPEC survey, only two permit topics outside the subject of librarianship; equal weight was given to library and nonlibrary publications by fifty-four ( 65.9 percent) of ARL directors responding to the Geahigan et al. survey.

31. Charles A. Schwartz, "Research Productivity and Publication Output: An Interdisciplinary Analysis," College \& Research Libraries 52 (Sept. 1991): 420-21.

32. John Budd. "Publication in Library \& Information Science: The State of the Literature," Library Journal 113 (Sept. 1, 1988): 125.

33. Park and Riggs, "Status of the Profession," 282.

34. Budd and Seavey, "Characteristics of Journal Authorship by Academic Librarians," 464.

35. David F. Kohl and Charles H. Davis, "Ratings of Journals by ARL Library Directors and Deans of Library and Information Science Schools," College \& Research Libraries 46 (Jan. 1985): 40-47; Sylvia C. Krausse and Janice F. Sieburth, "Patterns of Authorship in Library Journals by Academic Librarians," Serials Librarian 9 (Spring 1985): 127-38.

36. Mary T. Kim, "Ranking of Journals in Library and Information Science: A Comparison of Perceptual and Citation-based Measures," College \& Research Libraries 52 (Jan. 1991): 24-37.

\section{APPENDIX A}

Librarians, as members of the faculty, strengthen their competence in the field by performing research and scholarship relevant to their faculty appointment. They disseminate the results of their work through means appropriate to their specialty, such as publications, lectures, and exhibits; and by participation in appropriate technical, professional, and scholarly societies that reflect their research or artistic reputations. In weighing research and scholarship contributions, a number of factors must be considered.

\section{The Work}

- How much research and scholarship is evident in the preparation of the work?

- Is the work well presented? Is it properly documented, well focused, and organized in a logical manner? Is it timely?

- What is the degree of originality, creativity, and innovation in the work?

- Does the work place the topic in a broader professional context? Is that context well represented?

- Does the work stimulate further thought, study, or research? 
- Are there reviews of the work and what is the content of those reviews?

- What is the impact of this work on the field? What is its level of contribution to the body of scholarly knowledge?

- Are the findings significant? Are they applicable in any broad way?

- What is the significance of the work compared to other works by the author and to works by other authors in the same area?

- Is it a contribution which adds value to an existing work or a core program?

- Is the work relevant to the faculty member's role?

- Does the work benefit or contribute to the goals of the library or the mission of the institution?

- Is the proper methodology used? Is it applied appropriately? Does the author apply new methods or use old ones in a new way?

- Is there critical acclaim or citation by other scholars?

\section{The Author}

- What are the qualifications of the author to speak to this particular topic?

- Are the author's qualifications apparent in the article's scholarship?

- How well does the author develop the ideas?

- In co-authored works, what is the level of participation for each author?

- Does the author communicate clearly?

\section{The Presentation Forum}

- What is the reputation of the forum in which the work is presented?

- Is the forum local, regional, statewide, national, or international?

- Does the acceptance process include critical review of the work through a referee process? 